\title{
CHEMICAL COMPOSITION OF ESSENTIAL OIL OF BACCHARIS SALICIFOLIA (RUIZ \& PAVON) PERS. AND ANTIBACTERIAL ACTIVITY
}

\author{
ROBERTO CARRIZO FLORES ${ }^{1, *}$; MARTA PONZI' ${ }^{1}$ CARLOS ARDANAZ ${ }^{2}$; \\ CARLOS E. TONN² AND OSVALDO J. DONADEL ${ }^{2, *}$
}

\begin{abstract}
${ }^{\prime}$ Área de Quimica. INTEQUI-CONICET-FICES. Universidad Nacional de San Luis. Av. 25 de Mayo 384 Villa Mercedes, San Luis, 5730, Argentina.
2 Área de Química Orgánica. INTEQUI-CONICET- FQByF. Universidad Nacional de San Luis. Chacabuco y Pedernera. San Luis, 5700, Argentina.
\end{abstract} (Received: April 24, 2009 - Accepted: June 22, 2009)

\begin{abstract}
The essential oil of the aerial parts of Baccharis salicifolia was examined by GC and GC-MS and the major components were identified as $\alpha$-pinene, camphene, $\beta$-pinene, $\alpha$-phellandrene, $\alpha$-cubebene, $\beta$-cariophyllene, 6,9-guaiadiene, germacrene $\mathrm{D}$ and germacrone. The essential oil was tested against eight Gram positive and Gram negative bacteria. The essential oil was found to exhibit moderate antibacterial activity against Gram positive bacteria tested with MIC values from 0.47 to $0.94(\mu \mathrm{g} / \mathrm{ml})$.
\end{abstract}

Keywords: Baccharis salicifolia, Essential oil, Antibacterial activity.

\section{INTRODUCTION}

Food-borne diseases are still a major problem in the world, even in developed countries ${ }^{1}$. A variety of microorganisms can lead to food spoilage including Escherichia coli, Staphylococcus aureus, Klebsiella pneumoniae, Listeria monocytogenes, Salmonella sp. and Bacillus cereus ${ }^{2,3,4}$.

Raw and/or processed food is open to contamination during the production, sale and distribution steps. Food preservation is a relevant and complex problem. Food products require a longer shelf life and greater assurance of being free from food-borne pathogenic and spoilage organism. The excessive use of synthetic preservatives has resulted in an increasing pressure on food manufacturers either to completely remove chemical preservatives or by the use of new alternatives that consumers conceive as "natural or safe". In this context, essential oils derived from Baccharis $s p$. (Asteraceae) have been found to possess significant bioactivities. Several species of this genus are used in folk medicine as diuretic, digestive, and liver protector agents ${ }^{6}$. However, very few reports on the composition of the essential oils of the Baccharis species have been published?

\section{Experimental Section}

Plant material.

The aerial parts of Baccharis salicifolia were collected in February 2007, in El Volcan, Province of San Luis, Argentina and a voucher sample was deposited at the Herbarium of the Universidad Nacional de San Luis under number 9186-Del Vitto.

\section{Extraction of EO.}

The EO of fresh aerial samples $(5000 \mathrm{~g})$ was isolated by hydrodistillation for $3 \mathrm{~h}$, using a Clevenger - type apparatus according to the method recommended in British Pharmacopoeia ${ }^{8}$. The distillated oil $(0.56 \mathrm{~g} / \mathrm{Kg})$ was dried over anhydrous sodium sulfate and stored in tightly closed darks vials at $4{ }^{\circ} \mathrm{C}$ until analysis. The oil has a golden color with an herbal odor.

Identification of components.

The $B$. salicifolia EO composition was determined by GC-MS through comparison of the major signals with previously published spectra. Retention times and mass spectral data were checked with those obtained from authentic samples and/or from the MS instrument library. Relative percentages of the major components were calculated by integrating the registered peaks. GC-MS experiments were performed on a ion trap GCQ-Plus (Finnigan, ThermoQuest, Austin, TX, USA) instrument with MS-MS program using a silica capillary column Rtx ${ }^{\circledR}$-5MS ( $30 \mathrm{~m}$ x $0.25 \mathrm{~mm}$ ID, $0.25 \mu \mathrm{m}$ ). The carrier gas was helium $\left(40 \mathrm{~cm} \cdot \mathrm{s}^{-1}\right)$. The port temperature was $200^{\circ} \mathrm{C}$ in the splitless mode with $1.0 \mathrm{ml}$ injection volume. The initial $\mathrm{GC}$ temperature was maintained at $40{ }^{\circ} \mathrm{C}$ for 2 min, then increased to $210^{\circ} \mathrm{C}$ at $2{ }^{\circ} \mathrm{C} \mathrm{min}^{-1}$, and maintained at this temperature up to $120 \mathrm{~min}$. For the analysis of low resolution MS, the ion trap mass detector was set in full scan mode from $\mathrm{m} / \mathrm{z} 50$ to $\mathrm{m} / \mathrm{z} 450$. For the analysis of product, the collision inducted detection (CID) method was used. The precursor was selected using tandem mass spectrometry (MS/MS) scan standard function, with 0.5 daltons peak-widths for the parent ion and dynamically programmed scans, as described previously9.

The main components detected in the samples here analyzed were: $\alpha$-pinene (6.6x10-4 \%), camphene (8.2x10-4\%), $\beta$-pinene (4.06x 10-3\%), $\alpha$-phellandrene $(0.0272 \%), \alpha$-cubebene $(5.176 \%), \beta$-cariophyllene $(65.16 \%)$, 6,9-guaiadiene $(5.18 \%)$, germacrene-D $(6.6 \%)$ and germacrone $(17.85 \%)$ which represent a $99.99 \%$ of the total area.

In order to find some correlations between the identified compounds (GCMS) and the ${ }^{1} \mathrm{H}$ NMR spectral data, a sample of the whole essential oil was analyzed by this technique. A series of multiplets at $\delta 0.70-1.20$ was consistent with several methyl groups on $s p^{3}$ carbons. This moieties are presented in several monoterpenes as $(+)$-camphene, $\alpha$-pinene, $\beta$-pinene, $\alpha$-terpinene, $\alpha$-felandrene, and sabinene. Broad singlets in the range of $1.5-1.8 \mathrm{ppm}$ were in agreement with allylic methyl groups typical of some monoterpenes, namely (-)-limonene, $\alpha$-terpinene, $\gamma$-terpinene, and sesquiterpenes as germacrone and germacrene-D. Doublets $(J=11 \mathrm{~Hz})$ at $\delta 3.45$ and 2.29 were consistent with the $\alpha$-protons to a ketone group, as the observed in the germacrone, and pulegone spectra. Finally, typical vinylic protons are presented in some volatile compounds as (+)-camphene, (-)-limonene, and $\beta$-pinene and the signals observed at 4.705.08 , were in agree with this functionality.

The IR spectrum (film) showed absorption bands at 3500-3400 (OH, broad and weak), 2968, 2631, 2862, 1682 ( $\alpha, \beta$-unsaturated carbonyl group) 1452 , $1446(\mathrm{C}=\mathrm{C}), 1100\left(\mathrm{C}-\mathrm{O}\right.$, weak $\mathrm{cm}^{-1}$. From the inspection of this spectrum, it is possible to conclude that the alcohol fraction was very low in the whole essential oil.

The study of the chemical physical characteristics of the essential oil, gave a refraction index of $1.5159,[\alpha]_{D}^{19}+24.37\left(\mathrm{CHCl}_{3}, c 0.0187\right)$, and a density value of $0.9264 \mathrm{~g} / \mathrm{ml}$. All the determinations were run at $19^{\circ} \mathrm{C}$.

These results are in agreement with those reported from samples collected in Bolivia ${ }^{10}$

\section{Microorganisms.}

The used microorganisms were four Gram positive bacteria: Bacillus cereus and Staphylococcus aureus from Laboratory of Microbiology of UNSL, Listeria monocytogenes CLIP 74903 and 74904 which were a gift from the Institute Pasteur, France, and four Gram negative strains isolated in the above mentioned laboratory of UNSL: Escherichia coli, Salmonella enteritidis, Salmonella typhimurium and Proteus mirabilis. All the tested strains were maintained at $4{ }^{\circ} \mathrm{C}$ in Tripticase Soy Agar (TSA) and were cultured every month.

Determination of Minimal Inhibitory Concentration (MIC).

The MIC values were studied for all bacterial strains, using the method suggested by NCCLS ${ }^{11}$. The inocula of the bacterial strains were prepared from $18 \mathrm{~h}$ broth cultures and suspensions were adjusted to $0.5 \mathrm{Mc}$ Farland standard turbidity. Then they were diluted 100 times. The EOs were first dissolved in 20 $\%$ Tween 80 and then diluted with phosphate buffer saline (PBS) to the highest concentration $7.5 \mu \mathrm{g} / \mathrm{ml}$ to be tested, and then serial two-fold dilutions were made in concentration ranges from 7.5 to $0.24 \mu \mathrm{g} / \mathrm{ml}$. In addition, gentamicine 
dilutions were prepared in a concentration range from 128 to $0.25 \mu \mathrm{g} / \mathrm{ml}$. The nutrient broth was tripticase soy broth (TSB) $\mathrm{pH} 7.2$ supplemented with $0.01 \%$ (w/v) 2, 3, 5-triphenyltetrazolium chloride for the visual indicator of bacterial growth. Microplate method (micro-well dilution) was used to determine the MIC. In brief, the 96-well plates were prepared by dispensing into each well 95 $\mu 1$ of nutrient broth and $5 \mu \mathrm{l}$ of the inocula (final concentration of $10^{4} \mathrm{CFU} / \mathrm{ml}$ ). One hundred microliters aliquot from the stock solutions of the EOs and their serial dilutions initially prepared was transferred into six consecutive wells. The final volume in each well was $200 \mu$ l. The plate was covered with sterile plate sealer and then incubated at $37^{\circ} \mathrm{C}$ for $24 \mathrm{~h}$. MIC was defined as the lowest concentration of the $\mathrm{EO}$ in the medium in which there was no visible growth after incubation ${ }^{12}$. The experiment was replicated at least twice.

\section{RESULTS AND DISCUSSION}

Baccharis salicifolia (Ruiz \& Pavon) Pers. is a plant mainly found in the Provinces of San Luis and Mendoza, Argentina. The aim of this work was to investigate the antibacterial activity of $B$. salicifolia essential oil (EO) against Gram positive and Gram negative bacteria, where three strains of food borne pathogenic bacteria were included.

The assessment of inhibitory activity of various antibacterial agents (from natural sources or by synthesis) can be performed by using the determination of the minimum inhibitory concentration of the antimicrobial compound in liquid media, and the measurement of the diameter of the inhibition zone of bacterial growth around paper discs impregnated with an antibacterial compound. In the present study, the first method was used to evaluate the antibacterial activity of the essential oil derivate from $B$. salicifolia. The corresponding results are shown in table 1 . The antibacterial activity was observed only toward Gram positive samples. The all Gram negative bacteria were resistant. The essential oil of $B$. salicifolia had the highest activity against $B$. cereus.

Table 1. Antibacterial activity of Baccharis salicifolia EO by Minimal Inhibitory Concentration (MIC) of B. salicifolia EO $(\mu \mathrm{g} / \mathrm{ml})$.

\begin{tabular}{|l|c|c|}
\hline \multicolumn{1}{|c|}{ Bacteria } & \multicolumn{2}{c|}{ MIC } \\
\hline S. aureus & B. salicifolia EO & Gentamicin \\
\hline B. cereus & 0.94 & $\leq 0.25$ \\
\hline L. monocytogenes CLIP 74904 ${ }^{a}$ & 0.47 & 2.00 \\
\hline L. monocytogenes CLIP 74903 $^{a}$ & 0.94 & 1.00 \\
\hline
\end{tabular}

${ }^{a}$ CLIP: Listeria Collection of the Pasteur Institute (Paris, France

The EO of B. salicifolia inhibited the growth of the selected Gram positive bacteria but was inactive against the Gram negative organisms tested. Most studies investigating the action of whole EOs against food spoilage organisms and food borne pathogens agree that, generally, EOs are more active against Gram positive than against Gram negative bacteria. That could be explained due the Gram negative organisms are less susceptible to the action of antibacterial, since they possess an outer membrane surrounding the cell wall, which restricts diffusion of hydrophobic compounds (typically the EOs components) through its lipopolysaccharide layer ${ }^{13}$.

\section{ACKNOWLEDGEMENTS}

We thank to UNSL (Projects 7301 and 50702), CONICET (PIP 6228) for the financial support of this study. OJD thanks to MAPFRE Foundation for the grant.

\section{REFERENCES}

1. Sokmen A, Gulluce M, Akpulat HA, Daferera D, Tepe B, Polissiou M, Sokmen M, Sahin F. Food Control. 15, 627, (2004).

2. Nigatu A, Gashe BA. Ethiop. Med. J. 32(4), 223, (1994).

3. Natta L, Orapin K, Krittika, N, Pattip B. Int. Food Res. J. 15(3), 337. (2008).

4. Stilles N. Antoine Van Leewenhoek. 70(2-4), 331, (1996)

5. Chorianopoulos N, Kalpoutzakis E, Aligiannis N, Mitaku S, Nychas GJ, Haroutounian SA. J. Agric. Food Chem. 52, 8261, (2004)

6. Cobos M, Rodriguez J, Oliva M, Demo M, Faillaci S, Zygadlo J. Planta Med. 67, 84, (2001)

7. Garcia M, Donadel O, Ardanaz C, Tonn, C, Sosa M. Pest Manag. Sc. 61, 612, (2005)

8. British Pharmacopeia. London; HMSO ed. (Vol. 2, pp. 137-138). 1988

9. Ardanaz C, Traldi P, Vettori V, Kavka J, Guidugli F. Rapid Commun. Mass Spectrom. 5, 5, (1991)

10. Loaysa I, Abujder D, Aranda R, Jakupovic J, Collin G, Deslauriers H, Ida Fan F. Phytochemistry. 38, 38, (1995)

11. NCCLS (National Committee for Clinical Laboratory Standards) Performance standards for antimicrobial susceptibility testing, In $9^{\text {th }}$ International Supplement, PA, M100-S9, Wayne. (1999)

12. Carson C, Hammer K, Riley T., Microbios. 82, 18, (1995).

13. Burt S. Int. J. Food Microbiol. 94, 223, (2004) 